\author{
Tomas Janeliūnas", Laura Kirvelyte** \\ Institute of International Relations and Political Science, University of Vilnius
}

\title{
Development of Georgia's Security Strategy: Tough Road Towards NATO
}

\begin{abstract}
Georgia's security alternatives in recent years have narrowed to a very concrete goal NATO membership. This kind of choice seems to be logical for a small state. Nevertheless, security strategy, based on the key goal of alliance with stronger partner, may cause several problems. In the case of Georgia, security dilemmas are even more complicated. Unresolved problems with separatist regions were permanent key obstacles for Georgia to become reliable NATO candidate. The more Georgia was streaming towards NATO, the more relations with Russia deteriorated. The flashpoint of growing tension was the blitzkrieg of August 2008 between Georgia and Russia. Nevertheless the results of war may seem to provide the possibility for Georgia to resolve internal problems: however they failed to provide any guarantees for NATO membership. In this research paper the question - whether striving for NATO membership could guarantee Georgia's security - is analyzed. Also, the main obstacles for the realization of Georgia's security strategy and key dilemmas for NATO, in dealing with Georgia's case, are discussed.
\end{abstract}

\section{Introduction}

The Blitzkrieg between Georgia and Russia at the time of Beijing Olympic Game unfolded the most painful aspects of Georgia's security strategy. From the moment of the disintegration of the USSR and the proclamation of Georgia's independence in 1991, until now, Georgia has been solving its problems of ensuring national security and guaranteeing territorial integrity. Russia's aggression and harsh defiance of the territorial integrity of a sovereign state once more proved fears to Georgia's government that frozen conflicts could anytime turn into bloody wars. What seemed to be impossible to happen in XXI ct., turned into a painful reality. When Russian armed forces penetrated further and further into Georgia's territory, the threat, that a sovereign democratic state can be fully occupied by other state, appeared. After Russia unilaterally recognized Abkhazia and South Ossetia, Georgia may claim the Russia was purposefully dividing the state.

\footnotetext{
" Dr. Tomas Janeliūnas is an associated professor of the Institute of International Relations and Political Science of the University of Vilnius. Address: Vokiečių str. 10, LT-01130 Vilnius, Lithuania, tel.: + 3705-2514130, e-mail: tomas.janeliunas@tspmi.vu.lt

** Laura Kirvelyte, M.A. is a graduate from the Institute of International Relations and Political Science of the University of Vilnius. Address: Vokiečių str. 10, LT-01130 Vilnius, Lithuania, tel.: + 370-5- 2514130, e-mail: laura.kirvelyte@gmail.com
} 
The government of Georgia, by the help of mass media, encouraged the international community not to leave indifferent in relation to a state suffering from aggression. Russia's aggression had to be a kind of confirmation, that Georgia's efforts to become part of NATO and to get collective security guarantees as soon as possible were well-grounded. From the time of the Rose revolution and Mikheil Saakashvili becoming the president of the state, this small South Caucasian state has chosen a difficult, but clear-cut way towards NATO. This goal of Georgia is unsatisfactory to Russia and a great "headache" for bigger part of Alliance. The results of the Bucharest summit in the spring of 2008 showed several members of NATO avoided irritating Moscow and refused to give the Membership Action Plan (MAP) to Georgia and Ukraine.

The conflict between Russia and Georgia for most states of the EU and NATO was the turning point to re-evaluate Russia's actions and the stage of relationships with Moscow. Representatives of NATO and even several of the most faithful partners of Moscow in Europe (for example, Germany) were the first to state that the conflict does not cancel the possibility of Georgia becoming a NATO member. Nevertheless, until no clear decision of the perspectives of Georgia's NATO membership are taken, the question - will Georgia ever get collective defence guarantees from NATO - is still present. When the hottest of the emotions cooled down, it became clear that the NATO members who doubted Georgia's reliability at the end of 2008 strengthened their arguments why it is not worth it to be in a hurry, granting Georgia and the Ukraine MAP. Even the USA declared that to press the granting of MAP for Georgia means to raise the voltage in relations with Russia, and at the same time, to minimize the possibility of restoring stability in the South Caucasus. For this reason at the eve of the summit of NATO, foreign ministers in December of 2008 the State Secretary of the USA, Condoleezza Rice, stated that the USA has stepped back from the demand for NATO to prepare the plan of admission of Georgia and Ukraine. Nevertheless, it was stated, that the perspective of NATO membership has not been cancelled and both states are encouraged to start the necessary reforms without the official MAP.

In this research paper, key challenges and threats for Georgia, also Tbilisi's efforts to ensure its security, will be overviewed. Georgia's security strategy has transformed several times during the period of independence. Every time, the security strategy reflected efforts to find an optimal balance between internal security problems and defence from external threats. It is not easy to find the right solution; Georgia carries not only the problem of separatism, but also has a huge and unfriendly neighbour who is likely to manipulate with the leverages of the security of other state.

Even before the August war, Georgia encountered a difficult dilemma, to stream towards NATO, but because of Russia's ambitions, the risk of finally losing the separatist regions of Abkhazia and South Ossetia, or to go to concession in relations with Moscow and to hope that it will not stimulate tendencies of separatism in Georgia.

Georgia has chosen the way of integration into Euro-Atlantic structures and has attained a aggressive response form Russia. Till now Georgia's 
NATO, and even more, their EU membership, is only at the stage of a goal to reach. From the security perspective Georgia is vulnerable more that ever before. For this reason the question, can Georgia's choice of NATO membership guarantee the security of the state, arises. This question is the key point of the research paper. The answer to this question will be researched analyzing the theoretical opportunities of security of a small state and the development of Georgia's security strategy. Also the main reasons complicating Georgia's efforts to ensure their national security will be discussed. Viewpoints of the main actors of the international community toward Georgia's security strategy will be reviewed.

The war between Russia and Georgia highlighted the vital need for a small state to ensure its national security with the help of international organizations or alliances. Lithuania reacted very sensitively to the events in Georgia, because Russia's aggression reminded them that a small state can anytime become the victim of the aggression of great power or the object of manipulations. Nevertheless Lithuania now is a full member of NATO, yet it does not eliminate the sense of insecurity because the impact on a small state can be reached not only using military tools. What is more, in the context of Russia's - Georgia's war the discussions on the efficiency of NATO as a collective defence alliance took place. To be more exact, solidarity in implementation of collective defence for Lithuania was the key stimulus to strive for NATO membership. In fact, the same argument is the main stimulus for Georgia's NATO membership. But efforts of Georgia to become a NATO member as soon as possible disclosed not only the internal security problems of the state, but also the different position of current NATO members on potential obligations in the sphere of security. This cleavage raises a more serious question - does the NATO membership really guarantee the security for a small state?

\section{Security Strategy of a Small State: Possibilities and Limits}

\subsection{Insecurity - Permanent Problem of a Small State}

Reflecting contemporary tendencies, it can be stated that one of the main characteristics of a small state is its vulnerability. Although when evaluating the qualitative parameters (GDP per capita, parity of purchasing power (PPP), mean salary, etc.), small state can be equal or even more developed than big state $^{1}$, a small state disposes a small amount of quantitative resources: area,

\footnotetext{
1 Brautigam, D. and Woolcock, M., Small states in a global economy. The role of institutions in managing vulnerability and opportunity in small developing countries. United Nations University, July 2001, 2 (Discussion paper No. 2001/37)
} 
financial, human resources. That is the key reason why a small state is vulnerable by pressure from the outside.

After the major changes in XX ct. in the international system took place (especially - World War I, the collapse of colonial system, the end of Cold War and the collapse of USSR), more opportunities for a small state's self-sufficiency were present. Nevertheless, the majority of small states, especially - new formed, found themselves in "the zone of high geopolitical voltage" - in the space of intersection of interests of great powers. So, under such tense circumstances and in the absence of convenient geopolitical position, small states have been hustled to maintain their national security in an active way, searching for external sources of security. As Steven L. Spiegel emphasized, in the international arena big states (great powers) use to act like a "suppliers" of power/security, at the same time small states fulfil the role of the "consumers" of power or additional security guarantees ${ }^{2}$. "Supplier" and "consumer" are connected by the symbiosis relationship: "consumer" (the small state) gets from the "supplier" (great power) additional security guarantees, which enables the small state to maintain it's statehood, while the "supplier", by the help of this process, gets an opportunity to spread it's influence and attain additional leverages of structural strength. It is worth mentioning that the "supplier" of power/security to a small state can be not only a big state, but also another entity recognized as the actor of international relations (for example, the EU, NATO, etc.). Olav F. Knudsen is even more radical in this question. He describes small states as "net security importers", or actors of the international arena, which trying to preserve its maintenance, needs more support from the outside that they can give back ${ }^{3}$.

Because of the vital need of the external source of security, small states, which appeared as a result of a formation of a contemporary international system (new small states, appeared after the end of the Cold War), can be defined by one more feature - adaptivity. When the source of security weakens, the small state faces the need to reconsider its security choices. Adaptivity for the small state is of the same importance as power for big state because it guarantees maintenance of statehood.

In addition, the compulsory circumstance for the small state to get additional security guarantees is its importance to the supplier: the small state must be objectively important to "supplier" or to present itself as an important actor in relation to great power and convince the "supplier" of its importance (subjective criterion). The idea that will be developed further in this research paper is that the emphasis of Georgia's importance for the West (especially - for the USA) and permanent efforts to attract the attention of the Western partners became the key elements of Georgia's security policy.

2 Spiegel, S. L., Dominance and diversity. The international hierarchy, Boston, 1972, p. 133, 136.

3 Knudsen, O. F., "Small states, latent and extant: towards a general perspective", JIRD, 2002, No. 5(2), p. 187. 


\subsection{Security Strategy - Reflection of Behaviour of a Small State}

There are discussions in the academic space regarding whether small states are able to choose self-sufficient directions of its foreign and security policies, or do great powers overtake the right of decision making from the small ones. It is agreed, that the impact of small states for the world politics is not big because of a disproportion of powers (both relational and structural dimensions) between big and small states. But the most attractive seems to be the "middle" position, which states that nevertheless international conjuncture sets several restrictions on the choices for security of a small state, the final combination of choices belongs to the competence of the state. This combination of choices is considered to be the security strategy - the complexity of long-term political choices in the sphere of foreign and security policy, being fixed in the strategic documents (Concept of national security, Strategy of national security, Strategy of foreign policy, Military strategy) and constantly appearing in political practice. If permanent political practices do not coincide with the principles fixed in the strategic documents, then the principles, which are evident in political practices, are taken as a background of security strategy.

Security strategy fulfils two functions. First, it informs other actors in the international arena about the directions of the foreign and security policy of the state. It increases transparency and the level of predictability of the state, which is what defines the state as more trustworthy. This is especially important for small states, because it helps to create prestige in the international arena and to increase structural power disposed by the state. Second, the security strategy, especially if fixed in strategic documents, helps to ensure the continuality of foreign and security policy. It is especially important in the process of the changing of ruling elites.

Security strategy is composed of two categories. The first category - is the directions of foreign policy and security policy, chosen by the small state and recognized by the "supplier of security" (guarantees in the sphere of foreign policy and security). But if security strategy would include only guarantees, the concept would be very narrow. As far as security strategy it includes not only the position of the state in relation to other actors of international arena, but also the manner of the behaviour of the state in the international arena. The second category of the security strategy - aspirations - is also very important. Aspirations define potential (possible) future guarantees (if small state continuously seeks some guarantees, it is a possibility, that one day it will obtain them). Also aspirations act like a determinant of the ways and manner of policy of small state. So it can be said that both the existing guarantees and aspirations can be considered as long-term political choices.

Alliance - one of the most popular security strategies among small states (neutrality and complementarism also are considered to be typical security strategies for small states). Alliance as security strategy can assume different forms: great powers' alliance, alliance of small states and mixed alliance (of 
small and big states $)^{4}$. The main advantage of alliance are a clear-defined course, aims and priorities of foreign and security policy. Because of clear-defined "supplier of security", consensus on the directions on foreign and security policy is being reached more easily inside the state. By such conditions, the rotation of ruling elite does not act like a threat to the continuality of the security strategy of the state. What is more, the alliance is more stable than the other two security strategies: the state, once having made its choice, does not have to overlook periodically its decision. The main shortcomings of this security strategy are the - strong dependence from the "supplier of security" and lack of alternatives. In the case of the weakening of the "supplier of security", the small state is forced to look for the new "supplier" or to change the whole security strategy. A certain level of dependence from the possibilities of the partner of alliance (or even from strategic goals of the partner of alliance) in the long run can restrict small state and turn it into the hostage of the fall of great power, or of the shift in it's grand strategy.

Georgia, which in their particular period was doubting its final choice and trying to balance between great powers, the after year 2003 had chosen their security strategy based on an alliance with NATO and extremely intensive relations with USA. This choice of Georgia was not easy both because of difficult internal security situation of the state and also complicated external circumstances. Nevertheless the directions of Georgia's security strategy in the level of aspirations are very clear-cut, Georgia still has no guarantees from the side of "supplier" of security. This vacuum between "demand" and "supply" for security is the main source of concern for Georgia.

\section{Georgia's Security Policy until the "Rose Revolution"}

After the end of Cold War, newly independent Georgia was faced with a very difficult security situation; the state not only had two unsuccessful wars with separatist regions of Abkhazia and South Ossetia, in consequences of what have faced permanent threat to its territorial integrity, but also had to reconcile to Russia's influence.

Nevertheless the period after the Rose revolution seems as a clear breakpoint from a balance between Moscow and Washington towards security strategy of alliance with Washington, it would be more exact to name Georgia's security policy till Rose revolution as step-by-step shift towards alliance with the West. As it has already been said, one of the most vital criterions for alliance enduring consensus between inner political forces and in the society for the main vector and issues connected of the foreign and security policy. In the case

${ }^{4}$ Wiberg, H. "The security of small nations: challenges and defences", Journal of Peace Research, 1987 Vol. 24 No.4, p. 343. 
of Georgia, differences between political forces have been on national issues only, to be more exact - on the scope of freedom for national minorities. At the same time Russia has never been considered as serious security guarantee by any of the relevant political forces in Georgia.

\subsection{Gravitation of Separatist Regions towards Russia}

The first tensions in Georgia, which was historically multicultural (in the territory of Georgia inhabitants of different nationalities - Abkhazians, Ossetians, Armenians, Azeris - have lived) took place at the period of perestroyka. Nevertheless tensions at this time were present in relations with all national minorities, the most intensive tensions, which turned to conflicts later, were present in relations with those ethnic minorities, which had no "mother" state. For example, the number of Armenians in the Samckhe-Javakheti region, or the amount of Azeris in the Kvemo Kartli region, were significant bigger than the number of Abkhazians or Ossetians, tensions with Armenians, as far as with the Azeris they did not reach the stage of conflict. It can be supposed, that the desire of the Abkhazians and Ossetians to guarantee self-security, and for this reason to demand autonomy or even independence, was greater because those nations had less alternatives for the long-lasting existence.

Both the conflicts in Abkhazia and south Ossetia hold ethnic character. One of the main impulses of these conflicts was the nationalistic policy of the first president of newly independent Georgia Zviad Gamsakhurdia. On the one hand, Russia had immediately used the factor of newly-emerged tensions, which led to the long-tem freeze of these conflicts. On the other hand, the causes of both conflicts came from within the country.

In 1991, Georgia proclaimed itself an independent and unitary state (without autonomous regions). After the abolishment of the possibility for autonomy, unrest with Abkhazia, which previously had the status of autonomous republic, began. It is worth mentioning, that frozen conflicts in post-soviet space - were phenomenon caused by several reasons. The first reason is the fact that after the disintegration of USSR, only soviet republics got independence. Autonomous republics, which were formed on the basis of ethnicity, had no right to independence. The second reason, why frozen conflicts emerged, was the efforts of Russia to turn these ethnic tensions to long-lasting conflicts.

Abkhazia, which historically never has been the part of Georgia, was incorporated in year 1931 into Soviet Georgia by the order of Yosif Stalin. After the disintegration of USSR Abkhazia, following the existing rules became an integral part of newly-independent Georgia. But at the end of ninth decade of $X X$ ct. the threat of separatism seemed not to be an issue because the number of ethnic Abkhazians in the regions was slightly lower than 20 percent. Neverthe-

\footnotetext{
5 Svante C., Authonomy and conflict. Ethnoterritoriality and separatism in the South Caucasus - cases in Georgia, Dissertation for the degree of Doctor of Philosophy, Uppsala University, 2002, p. 173.
} 
less, the nationalistic policy of Gamsakhurdia was an impetus for the Abkhazian minority to rethink the possibilities of maintaining their identity. The intent to secede from Georgia has been clearly shown in March 1989 already and in July of the same year clashes with the central authority began. The turning point, which led from ethnic tensions to clashes, was the attempt to open the branch of Tbilisi University in Abkhazia's regional centre Sukhumi.

In year 1992, Georgia's military forces entered Abkhazia. Military actions began. Nevertheless Tbilisi was expecting blitzkrieg, military actions took place till 1993. During this period Abkhazia received many-sided assistance from Russia; Russia supported breakaway region by weapons, humanitarian aid and human resources (Abkhazian military forces were strengthen by Chechen militaries $^{6}$ ). In October of 1993 Georgia and Abkhazia signed a Russian-supported cease-fire agreement. Russian peacekeepers (under the mandate of CIS) were dislocated in the region and the conflict became frozen ${ }^{7}$.

Negotiations for the settlement of the conflict between Georgia and Abkhazia took place in bilateral format. The separatist region was demanding full independence from Georgia, but Georgia was ready to offer not more than a broad autonomy. Also the process of negotiations had been frozen because of a disagreement over the question of internally displaced persons (IDP): Georgia had stated, that the legal status of the region will be resolved only after all IDP will be returned to Abkhazia, but Abkhazia had demanded the resolution of legal status as an obligatory precondition for returning of IDP to the region. Abkhazians have feared that after the returning of non-Abkhazian IDP to the region, Abkhazians would again become the only ethnic minority and would not be able to protect their interests anymore.

One of the greatest problems in the process of the regulation of Georgia's -Abkhazia's conflict is the asymmetry of power, caused by the huge influence of Russia and poor international involvement. The only international organization, which has been involved in the process of resolving the conflict, is the United Nations (UN). In 1992, a month after the beginning of military actions, the UN sent a fact-finding mission to the region. In the spring of 1993, a special envoy was nominated of UN going to Abkhazia (Swiss diplomat Eduard Brunner took this position). The same year Georgia asked the UN to dislocate the peacekeeping mission in Abkhazia. The UN Security Council decided to make a compromise decision (Russia - permanent member of UN Security Council) and sent to Abkhazia not peacekeepers, but military observers, United Nations Observer Mission in Georgia - UNOMIG. The main task of UNOMIG was to monitor how Russian peacekeepers implement cease-fire regime ${ }^{8}$.

When international attention towards the Abkhazian conflict increased,

\footnotetext{
${ }^{6}$ Sabanadze N., International involvement in the South Caucasus, European Centre for Minority Issues, February 2002, p. 12 (Working paper no. 15).

${ }^{7}$ Lynch D., Why Georgia matters, Institute for Security Studies, February 2006, p. 17-18 (Chaillot paper No. 86).

${ }^{8}$ Bartuzi W. et. al. Abkhazia, South Ossetia and Nagorno-Karabakh: frozen conflicts between Russia and the West, Warsaw: Centre for Eastern Studies, 0907 2008, p. 5.
} 
one more international actor became involved in the conflict regulation process - a Group of friends of the UN Secretary General, composed of diplomats from the USA, Great Britain, Germany, France and Russia. The function of the Group of friends has been to mediate the dialogue between Georgia and breakaway Abkhazia.

In the case of South Ossetia, such a harsh interethnic tension has not taken place. South Ossetia also had never been a historical region of Georgia. It was separated from contemporary North Ossetia and integrated into Georgia in 1922. In 1989, the Supreme Council of South Ossetia asked the central authorities of Georgia to grant the region a status of an autonomous republic (the same as for Abkhazia), but demonstrated desire to remain within Georgia $^{9}$. At this time nationalistic tendencies were extremely popular in Georgia, so the request of South Ossetia was rejected. What is more, it was decided to abolish the status of an autonomous region. President Eduard Shevardnadze later called this step "the greatest mistake of Georgia".

The abolishment of the status of an autonomous region provoked military reaction from the side of South Ossetia. Military actions started in 1990 and were "frozen" in 1992, when Shevardnadze and Russian president Boris Yeltsin signed cease-fire agreement ${ }^{10}$. In the same year, a mixed peacekeeper contingent composed of Georgian, Russian and South Ossetian peacekeepers was dislocated in the region. Peacekeepers have been supervised by the Joint Control Commission (JCC), which is composed of Georgian, Russian, South Ossetian and North Ossetian representatives. Georgia permanently demanded to improve this format, abolishing the asymmetry of power, because Russia in JCC really has three voices, and Georgia - only one. But any changes in the format can be made only by unanimous accord of all members. For this reason no improvements were ever made.

Russia step-by-step expanded its influence in the zones of frozen conflicts, increasing the level of de facto integration of these regions into Russia. First, separatist regions during the war with Georgia were widely supported by Russia ${ }^{11}$. Second, even after cease-fire agreements were signed, Russia has never stopped arming separatists regions to make the peace process as slow as possible. Third, Russia has always supported de facto regimes, for example, paying salaries for representatives of de facto authorities. What is more, Russia, whose citizens are more than 80 percent of inhabitants of breakaway regions ${ }^{12}$, has been paying pensions, allowances and other social payments to them. Fourth, Russian business enterprises are well represented in the region. So, Russia, by the help of political, social, military tools, also - the policy of citizenship, has encouraged separatist regions to gravitate towards Russia, at the same time complicating the perspectives for reintegration of Georgia.

\footnotetext{
9 Sabanadze, (note 6) p. 15.

${ }^{10}$ Lynch, (note 7) p. 18.

${ }^{11}$ Sabanadze, (note 6) p. 13, 17.

${ }^{12}$ Bartuzi W. et.al., (note 8) p.5-6.
} 
It is worth mentioning, that the policy of Russia towards ethnically different regions is very ambivalent. In the framework of it's own territory Russia is speaking about the principle of total territorial integrity, not being ready to make any concessions for, for example, republics of North Caucasus. But, in relation with other states sensitivity of Russia towards the question of nationality increases enormously. This dichotomy between values in internal and external policy appears because frozen separatist conflicts - one of the strongest leverages maintaining Russia's influence in post-soviet countries. For example, Georgia, like Azerbaijan, after proclamation of independence rejected to enter newly-established CIS. But after an unsuccessful war in Abkhazia, Russia "encouraged" Georgia to enter the CIS. What is more, the agreement of dislocating four Russian military bases in the territory of Georgia was also signed. What is interesting is that even cease-fire agreements, which normally are signed between conflicting states, in both cases were signed between Georgia and Russia. It supports the idea that it is more precise to consider Russia as a conflicting part than as a neutral mediator.

\subsection{Shevardnadze's Equilibrium between Russia and the West}

After the restoration of independence, Georgia has chosen a pro-Western vector of foreign and security policy and in 1992 became a member of the North Atlantic Cooperation Council. But in 1993, after unsuccessful military actions in Abkhazia, Georgia was forced to enter CIS. Nevertheless joining a Russiadominated organization restricted possibilities of development for pro-Western foreign policy, in 1994 Georgia was involved in a NATO-led Partnership for peace programme.

All during the last decade of XX ct. Georgia was forced to balance between the desire to intensify cooperation with NATO and the need not to irritate Russia, whose influence because of frozen conflicts of Abkhazia and South Ossetia, significantly increased. What is more, Georgia at that time was totally dependent on Russia's oil and gas.

Shevardnadze's efforts to maintain the balance between Russia and the West gave the results at the period of Yeltsin's presidency, but when Vladimir Putin became the president of Russia, Russia's pressure on Georgia began to increase. In the year 2000, expressing dissatisfaction with Georgia's pro-Western policy, Russia introduced a visa regime for Georgia. ${ }^{13}$ At the same time a visa regime for Abkhazia and South Ossetia was not introduced, and this served for further separation of the breakaway regions from Georgia and for stronger de facto integration of them into Russia.

In 1999, in Istanbul, a meeting of the heads of OSCE took place during which Russia took responsibility to withdraw its military bases from the ter-

\footnotetext{
${ }^{13}$ Falkowski M., Russia's policy in the Southern Caucasus and Central Asia, Warsaw: Centre for Eastern Studies, June 2006, p. 51.
} 
ritories of Georgia and Moldova. But Russia simply ignored these obligations for many years (military bases from the territory of Georgia were withdrawn only at the second half of 2007). Georgia's dissatisfactory with Russia's policy was increasing.

The tension between Russia and Georgia started to grow in 1999 already, when second Chechen war started. Russia requested Georgia to give permission for Russian military forces to enter Georgian territory and to attack Chechnya from the side of Georgia (Georgia - the only foreign state, which borders Chechnya). What is more, Russia was asking for permission to use the military airport of Vaziani (nearby Tbilisi) and Russian military bases, dislocated in the territory of Georgia, for the purposes of attack on Chechnya. All these requests were based on the premise, that Chechen fighters receive backup through the Georgian-Chechnya border, which goes by the Great Caucasian Mountains. All requests of Russia were rejected by Georgia as groundless, because according to representatives of Georgia, it is mostly impossible to cross Georgian-Chechen border, and in the winter Great Caucasian Mountains become impenetrable. According to such conditions, the premise of carrying weapons through mountains is absolute nonsense. ${ }^{14}$

In the year 2002, Russia again addressed the authority of Georgia with the request for allowance to introduce its military forces to Pankisi gorge, which according to Russia, Chechen terrorists are hiding. ${ }^{15}$ Georgia, instead of giving permission for Russian military forces to enter the Pankisi gorge, decided to organize two security operations in Pankisi - in January and August of 2002. According to the results of these operations, none of the Chechen terrorists were hiding in the gorge. But these conclusions did not calm Russia: Russia criticized security operations as carrying demonstrative character and being ineffective.

Both Georgia and USA were worried about Russia's military air forces, conducting unsanctioned violations of Georgia's air border. Several times Russian air forces, claiming to cross Georgia's air border inadvertently, bombed Georgian villages. In August 2002, after the last Georgian-led security operation in Pankisi gorge, Russian air forces invaded into Georgia and bombed Pankisi gorge individually. This was the last step, which forced Shevardnadze to take the decision for Georgia's integration to NATO.

On the $1^{\text {st }}$ of November 2002, a special governmental commission prepared the programme of Georgia's integration to NATO in military, economic and political spheres. In the same year at the Prague summit Georgia for the first time officially declared its desire to become a member of NATO in the future and intent to join the new programme - Individual Partnership Action Plan (IPAP).

\footnotetext{
${ }^{14}$ German T., Faultine or Foothold? Georgia 's relations with Russia and the USA. Conflict Studies Research Center, UK Defence Academy, January 2004, p. 2-3.

${ }^{15}$ German, (note 14) p. 3.
} 


\section{3. "Go West!": NATO Membership as Keynote of Security Strategy}

\subsection{Victory of Saakashvili and Striving for NATO Membership}

At the end of 2003, after mass protests because of election frauds, the regime of Shevardnadze was forced to step down. After newly organized elections, the new president of Georgia became pro-Western Mikheil Saakashvili, who got absolute majority of the votes.

In the sphere of security policy, Shevardnadze's regime faced several difficulties. The greatest shortcoming of the system and ruling regime was that Georgia had no control of its own borders: separatist Abkhazia and South Ossetia operated as "black holes", and the crossing of the borders of breakaway regions was totally uncontrolled. What is more, internal security structures suffered the shortage of attention and money.

Georgia's NATO membership became the leitmotiv of Saakashvili's regime. Even at the time of Shevardnadze's regime, the tendency to rely on USA more than on Russia was clear. Nevertheless it has not grown to systematic vector of foreign and security policy of Georgia. But newly-elected Saakashvili overturned this balance immediately, declaring NATO membership the final goal of Georgia's foreign and security policy.

It is worth to mention, that the orientation of Georgia toward NATO was caused not only by internal factor - pro-Western regime of Saakashvili, but also by an external factor - the increase in Georgia's importance to the West. This happened because of four reasons:

- After the enlargement of NATO, the Alliance began to view Georgia as important link in the process of ensuring peace and security in South Caucasus. Unresolved conflict between Armenia and Azerbaijan, frozen relations between Armenia and Turkey, the threat of potential separatism of the breakaway regions of Georgia - these facts have always warned, that the South Caucasus anytime may become the flashpoint of cross-border conflicts.

- Strategic importance has increased after the USA has been involved in wars in Iraq and Afghanistan. Also, more and more tensions between USA and Iran have been rising. Potential help for stabilizing Iraq and especially - support during the conflict with Iran increased the level of attention of the USA towards Georgia.

- It was thought, that pro-Western Georgia, supported by NATO, would serve as a barrier, which would obstruct the spread of Russia's influence to South Caucasus. Together with the Ukraine, which had gone through Orange revolution, Georgia became an important element in blocking Russia's influence. 
- Georgia became relevant in the Western agenda for the wide-range projects in the sphere of transportation of oil and gas, which were operated in South Caucasus. The efforts of hydrocarbon-rich Azerbaijan to deliver oil and gas to world markets not only through Russia, turned Georgia into important transport link and guaranteed Western attention. In the middle of 2006, oil pipeline Baku-Tbilisi-Ceyhan began operating, at the end of the same year gas pipeline Baku-Tbilisi-Erzurum started functioning.

Nevertheless not all NATO members supported Georgia's membership, strong domination of USA in NATO let to the rapid development of GeorgiaNATO agenda.

In the year 2004, Georgia signed an Individual Partnership Action Plan with NATO. Signing of the IPAP was a signal of stepping to the second phase in the way to NATO. IPAP included cooperation in four spheres: political and security issues, issues of defence policy and military issues, issues of public information, scientific research and nature protection, civil crisis management, administrative, defence, security and resources management.

When IPAP was signed, intensive works of preparation began. In 2005, the special commission was established, which had to monitor the implementation of IPAP.

One of the key aspects in the way towards NATO was the establishment of the system of strategic documents. Shevardnadze was avoiding starting the preparation of such documents, because by the help of such documents the vectors and the most important long-term priorities of foreign and security policy of the state had to be fixed. In a situation, when it was lack of will to name Russia as strategic partner of Georgia, and the lack of ground to name USA as guarantee of Georgia's security, the optimal solution was to wait.

In 2005, Georgia's parliament passed and president approved the first National security strategy of Georgia, which has been the main strategic document of the country. In 2006, the National security strategy was modified, stepping from the principle of territorial defence to the principle of total and unconditioned defence. ${ }^{16}$ At the end of 2005 the National military strategy was passed. In this document, NATO membership was named as a guarantee of successful deterrence strategy. The last accent in the hierarchy of strategic documents became Threat assessment document ${ }^{17}$, which is reviewed annually.

In all these strategic documents it is emphasized, that Georgia seeks to become a part of USA-dominated alliance of collective defence and is not intended to allocate any resources for the development of Russia-dominated structures (CIS). ${ }^{18}$ The state's loyalty to USA is also proven by the fact that

\footnotetext{
${ }^{16}$ Ministry of Defence of Georgia, Strategic defence review. Final report 2007 unclassified, http://www. mod.gov.ge/2007/downloads/The_Strategic_Defence_Review(www.mod.gov.ge).pdf, 200809 10,p. 65.

${ }^{17}$ Ibid., p. 65 .

18 National Security Concept of Georgia, Tbilisi, 2006, http://www.mod.gov.ge/?1=E\&m=3\&sm=1, 2008 0420.
} 
Georgia, which has had relatively week military forces, has been contributing to the NATO mission in Iraq and has allocated the best-prepared forces to this mission. This kind of super-loyalty definitely gives some dividends in the political and economic sphere. In recent years Georgia became one of the main receivers of aid from the USA. From 1992, when Georgia began to get aid from USA, in the sphere of economy and social sphere Georgia received about 774 million dollars of aid. ${ }^{19}$ What is more, in September 2008, the Congress of USA confirmed a $1 \mathrm{bn}$. dollars aid package (which does not include aid for military sector), which will be provided for war-worn country within two years. It is worth to mention, that this amount of money over three times exceedsaid, which is being provided annually for all the region of South Caucasus and Central $\mathrm{Asia}^{20}$. For implementation of military reforms Georgia, as far as other states of South Caucasus, annually gets aid from the budget of USA. What is more, to provide help for military reforms in South Caucasus, the USA has initiated the foundation of South Caucasus Clearing House.

Nevertheless, super-loyalty in relations to USA also can have several shortcomings. First, it is not clear how long Georgia can keep special attention of USA and how the position of USA towards Georgia would change, if the USA should ask support connected to any international issue, from Russia. The risk remains that the USA, in the name of good relations with Georgia, would not be intended to worsen relations with Moscow. ${ }^{21}$ Secondly, it is not clear if the USA, which now finds itself under huge economic recession, be able to support Georgia financially in the nearest future. For Georgia, which now is only at the halfway of reforms, financial support is vital.

In the fall of 2006, after two years of signing IPAP (normally, the implementation of IPAP lasts two years), during the summit of foreign ministers of NATO, Georgia was offered to enter Intensive dialogue with NATO. It is important to mention that granting Georgia with Intensive dialogue shows the shift in the status of the state in relation to NATO from the partner to candidate. Intensive dialogue - bilateral package of instruments, designed to help the state to prepare for Membership Action Plan (MAP).

Summit of NATO heads, which took place on $2^{\text {nd }}-4^{\text {th }}$ of April 2008, was the greatest hope of Georgia to make grand jump towards NATO. Representatives of Georgia and Ukraine were expecting to be offered MAP. Unfortunately, due to lack of unanimity among members of alliance, two candidate countries were not offered MAP. Nevertheless, heads of NATO declared that NATO membership for Georgia and the Ukraine is only the question of time. ${ }^{22}$

Strong aspirations of Georgia and big progress in relations with NATO

\footnotetext{
${ }^{19}$ United States Agency for International Development (USAID) Georgia, About Georgia, http://georgia. usaid.gov/index.php?m=7, 20081002.

${ }^{20}$ Eurasiainsight, Kucera J., Georgia: US Congress approves reconstruction aid package for Georgia, 2008 09 30, http://www.eurasianet.org/departments/insight/articles/eav093008b.shtml.

${ }^{21}$ Civil Georgia, Russian, U.S. Diplomats Discuss Conflicts, 20070515 , www.civil.ge, 20070520.

${ }^{22}$ Eastweek, Ukraine, Georgia and Russia on the results of the NATO summit in Bucharest: reactions and forecasts, Issue 13(122), 9 April 2008, Warsaw: Centre for Eastern Studies, p. 4.
} 
(USA) leaves the hope, that someday Georgia will get firm security guarantees from NATO. The decision on MAP was delayed till the December of the same year. But how it got clear later, the last summit also has only weakly supported the vision of Georgia's NATO membership.

\subsection{Attempts to Solve the Problem of Separatism and Deteriora- tion of Relations with Moscow}

Saakashvili has inherited from the regime of Shevardnadze not only wide-spread corruption, but a very weak influence of central authority on regions. As The Economist noticed, Shevardnadze's Georgia was more like the combination of separate feuds, than modern unitary state. ${ }^{23}$ So, one of the first initiatives of Saakashvili was designed to strengthen core-periphery relations and to increase administrative effectiveness.

Adjaria, located on the coast of Black Sea, after the restoration of independence became one of the richest regions of Georgia. But political elite and administrative apparatus of the region was not only corrupt, but also involved into the actions of organized crime. So when Saakashvili came into power, ruling elite of Adjaria became afraid of the future changes and separatist moods began to appear. ${ }^{24}$ The ground to secede from Georgia for Adjaria was not present, because adjarians - ethnical Georgians, who were occupied by Ottoman Empire in the XIX century and overtook Islam..$^{25}$ In March of 2004 elections to the local parliament of Adjaria had to take place. Saakashvili demanded free and fair elections, otherwise threatened with blockade of the region. Leader of Adjaria, Aslan Abashidze, panicked, exploded bridges, connecting the region to the rest of Georgia and withdrew to Moscow. In May of the same year, parliamentary election in Adjaria was held. After the elections Georgia restored its control in Adjaria and granted the regional with broad autonomy.

After the successful case of a peaceful conflict solution in Adjaria, Saakashvili decided to apply the same framework for regulation of the conflict in South Ossetia. Unfortunately, the result this time was totally opposite. Why?

Nevertheless the case of Adjaria from the first glance seems similar to he cases of two other separatist conflicts in Georgia, the framework, which lead to restoration the control of Georgia in Adjaria, led even to more harsh resistance in Abkhazia and South Ossetia. This difference in results has been caused by several reasons:

- Adjaria, different from Abkhazia and South Ossetia, has no borderline with Russia. This factor restricted physical possibilities for Russia to interfere and to support separatist regime.

\footnotetext{
${ }^{23}$ Lynch, (note 7) p. 17.

${ }^{24} \mathrm{Ibid}$, p. $27-28$

${ }^{25}$ Svante, (note 5), p. 215
} 
- The conflict between Georgia and Adjaria took place in 2004, when at least minimal standards of democracy and the frameworks of behaviour of society were already formed. For this reason the influence by the help of demanding free and fair elections was possible. In the case of Abkhazia and South Ossetia, these regions separated from the influence of Georgia just after the dissolution of USSR, so they preserved the soviet style of political participation.

- The conflict in Adjaria had no ethnic aspect. At the same time people in Abkhazia and South Ossetia still remember nationalistic policy of Georgia after the restoration of independence and looks toward new initiatives of the central government with distrust.

In 2004, Saakashvili came to lead the country, which had two very deeply frozen conflicts that were not only a threat for the security, but also the main obstacle for integration of Georgia into Euro-Atlantic structures. So, the restoration of the territorial integrity of the state became the main task of the newly-elected president. In order to change harmful status quo, Saakashvili began intensive actions. Four directions of such actions can be distinguished.

- First, Saakashvili began to strengthen executive power. The powers of president were increased. What is more, the position of state minister (minister without ministry) for conflict resolution was established.

- Second, military capabilities of the state were also strengthened. After the Rose revolution, the decision to decrease the number of military forces from 38 thousand to 20 thousand was taken. According to the recommendation of USA International Security Advisory Board (ISAB), 13-15 thousand of regular military forces would be enough for Georgia. But, in reverse, the number of regular military forces has been gradually increased and at the end of 2007 reached 32 thousand. Expenditures for the military needs also have risen and now it takes the biggest part of budget. In the fall of 2007 Georgia's parliament passed initiative to increase the number of military forces by an additional 2.5 thousand soldiers. ${ }^{26}$ Since for NATO membership the quality of military forces is more vital that quantity, such a sharp rise in military forces without any doubts signalled that Georgia is ready to resolve frozen conflicts as fast as possible, not rejecting even military means.

- Third, Saakashvili's regime made clear distinction between de facto regimes of breakaway regions and inhabitants of the regions. So, the pressure has been made only on separatist regimes, at the same time inhabitants have been treated as citizens of Georgia.

- Fourth, in the search for effectiveness, there was an attempt to increase international involvement. One of the major tasks in the process of regulating frozen conflicts became the internationalization of formats of conflict resolution. Unfortunately, the task of internationalization of

\footnotetext{
${ }^{26}$ RFE/RL, Fuller L. and Giragosian, R., Georgia: what is behind expansion of armed forces?, 200709 19, http://www.rferl.org/content/article/1078720.html.
} 
the formats was not fulfilled, because any change in the format must be accepted unanimously. This means, that both Russia and separatist regions must accept the change in format, and this never happened. Nevertheless, in other spheres the efforts to increase international involvement gave results: the EU became the biggest financial donor in Abkhazia, peacekeepers in Abkhazia are monitored by UN (Geneva process), in South Ossetia OSCE is monitoring, how cease-fire regime is being implemented.

But, even with the presence of huge efforts from Georgia, the process of the regulation of frozen conflicts stays deeply frozen too. What it is more important, breakaway regions get more and more distant from Georgia. On the other hand, unsuccessful efforts of Georgia to normalize the situation in Abkhazia and South Ossetia gave Moscow a chance to interfere into internal politics of Georgia and to increase bilateral tension.

It could be said, that the situation created irresolvable strategic contradiction for Georgia: the more Georgia strived towards NATO, the more Russia increased tensions between Georgia on the one side, and breakaway Abkhazia and South Ossetia on the other side, and the more deep de facto integration of these regions into Russia took place. At the same time sceptics of Georgia's NATO membership have stated that Georgia could become the member of Alliance only after the restoration of territorial integrity. But the decrease in Georgia's aspirations for NATO membership could create favourable conditions for Russia to increase its influence in Georgia and in the long run, it could disrupt all plans of Georgia to become the part of the Alliance.

The decision of Georgia to improve the situation by the radical means in August 2008 could be inspired by political desperation: Saakashvili saw that political means were helpless both in trying to resolve separatist conflicts and in changing the opinion of NATO members, doubting of the possibility for Georgia's NATO membership. It makes no difference who would be named the initiator of military actions, political situation after August 2008 significantly differed from the situation in April 2008.

\section{Promise of NATO Membership and Challenges for Georgia's Democracy}

\subsection{Lithuania - Advocate for Georgia's NATO Membership}

Lithuania, which is a small state and also faces the security dilemmas of the small states, has actively supported Georgia's security strategy from the very beginning. The same way as Georgia, but much earlier, Lithuania chose security strategy of alliance with great power and has successfully implemented it. 
Lithuania's NATO membership became "the story of success", how a small state during relatively short period of time can transform its security systems and make integrate into Alliance. Lithuania's story strengthened the desire of newly-formed pro-Western regime of Georgia to follow the same framework and to strive for NATO membership. These intentions were strongly supported by Lithuania. What is more, Lithuania became the main advocate for Georgia's NATO membership in the Alliance.

On $14^{\text {th }}$ of October 2004, during the official visit of Saakashvili in Lithuania, a Joint declaration on regional cooperation and support for European and Euro-Atlantic integration was signed, in which Lithuania took an obligation to support Georgia's efforts for European and Euro-Atlantic integration and to provide assistance in the sphere of internal reforms. ${ }^{27}$ From this time a big number of bilateral and multilateral agreements and declarations were signed, in which clear support of Lithuania for Georgia's NATO membership is present. Lithuania has supported Georgia's efforts to transform its military and security system not only in political level, but also - by the help of practical actions. On the $8^{\text {th }}$ of February 2001 Lithuania and Georgia signed a bilateral agreement on cooperation in defence (military) sphere. Ministers of the defence on both sides of the agreement are meeting annually to discuss the main issues of the cooperation.

As declared in the reports of ministry of defence of Lithuania, practical cooperation is concentrated in the sphere of education of soldiers: officers of Georgia are taught in Lithuanian military academy and in Baltic Defence College at the expenses of Lithuania. What is more, specialists from Lithuania consult Georgia on the issues of public relations, in the spheres of logistics, standardisation and codification, shares experience in the sphere of introduction of new communication standards. Also, representatives of military forces of Georgia are being invited to observe military trainings in Lithuania and to also take part in traineeships in the sphere of defence planning and protocol. Since the spring of 2006, Lithuania has nominated a special advisor for the issues of preparation Georgia's Membership action plan (proto MAP). ${ }^{28}$

It is not surprising, that representatives of Lithuania were among the most active members, who supported the initiative of USA to grant MAP for Georgia and the Ukraine during the summit of heads of NATO in Bucharest in April 2008. The President of Lithuania Valdas Adamkus was actively involved in search for a compromise and contributed to the fact, that a phrase without precedent about the future prospects for NATO membership of Georgia and Ukraine was involved in final declaration. ${ }^{29}$ In the final declaration, the heads

\footnotetext{
${ }^{27}$ Lietuvos Respublikos užsienio reikalų ministerija. Lietuvos ryšiai su Gruzija, http://www.urm.lt/index. php?-1615992752, 20081004.

${ }^{28}$ Lietuvos Respublikos krašto apsaugos ministerija. Bendradarbiavimas su ne NATO šalimis. http://www. kam.lt/accessibility/index.php/lt/144572/.

${ }^{29}$ Lietuvos Respublikos Prezidento spaudos tarnyba, "Atëjo laikas čia ir dabar pakviesti Gruzija ir Ukraina pradèti igyvendinti NATO Narystès veiksmu planq", - sako Prezidentas V.Adamkus Šiaurés Atlanto Tarybos Viršūniu susitikime, 200804 03, http://www.president.lt/lt/news.full/8919.
} 
of Alliance stated that the membership of Georgia and Ukraine in Alliance is the question of time. Nevertheless, the decision, whether to grant the states with MAP, was delayed. The nearest date, when such a decision could be taken, was the summit of foreign ministers of NATO in December 2008. ${ }^{30}$ During the summit in Bucharest, one more condition for Georgia to get MAP was named commitment to preserve principles of democracy during the parliamentary elections in May 2008.

\subsection{Promise for NATO Membership in the Context of Unresolved Dilemmas}

During the NATO summit in Bucharest, differences between the positions of NATO members on the question of Georgia's and Ukraine's NATO membership became especially visible. USA, together with the closest allies Britons, Poles and representatives from Baltic States, obviously protected the possibility for Georgia and Ukraine to receive MAP as soon as possible. At the same time the heads of France, Germany and Italy, who are traditionally avoiding irritating Moscow, claimed, that it would be fair to consider interests of Russia this time and not to be in a hurry with giving NATO membership promises to Georgia and Ukraine. It was clear even before the Bucharest summit that it will be not easy to find compromise between those two opposing positions.

Sceptics of the quick granting of MAP to Georgia and Ukraine had enough arguments. Lack of stability in internal politics, sharp division in society and low support for the NATO membership were named as the biggest shortcomings of the Ukraine. The most essential shortcoming of Georgia was considered inability to resolve territorial conflicts in peaceful way. ${ }^{31}$

Trust in Georgia was decreased also because of the political crisis, which took place at the end of 2007, during which president Sakashvili made international community to doubt on his faithfulness for democracy. Protests of opposition, which took place in Georgia from September 2007 reached the peak in November, when police officers used force against the members of one protest action. This unrest encouraged Saakashvili to introduce a state of emergency. On the $7^{\text {th }}$ of November, a state of emergency was introduced: political meetings and translations of non-state TV stations were forbidden. ${ }^{32}$ The president and his representatives tried to explain, that unrest could be initiated by Russia, and that the state of emergency was necessary, trying

\footnotetext{
${ }^{30}$ Bucharest Summit Declaration. Issued by the Heads of State and Government participating in the meeting of the North Atlantic Council in Bucharest on 3 April 2008, http://www.nato.int/docu/pr/2008/p08-049e. html.

${ }^{31}$ Rytų Geopolitikos studijų centras. "Koki poveikị NATO viršūnių susitikime Bukarešte priimti sprendimai gali turèti geopolitiniams procesams Rytų erdvèje?”, žr. Rytu Pulsas, Nr. 1 (3), 200804 04, http://www. rytugeopolitika.lt/multisites/rytugeopolitika/images/stories/rytu_pulsas13.pdf.

${ }^{32}$ BBC, Georgia under state of emergency, 200711 08, http://news.bbc.co.uk/2/hi/europe/7083911.stm.
} 
to keep stability in the state. But this time even the closest supporters of the Saakashvili regime - Americans - doubted the argument of the possible involvement of Russia in internal unrest of Georgia. ${ }^{33}$ Supporters of Georgia in international community, including Lithuania, were encouraging Saakashvili to respect principles of democracy and pointed, that presidential elections at the beginning of 2008 will be attentively observed.

Events at the end of 2007 disclosed controversial, but very effective in the past Saakashvili's tactics, how to maintain attention of the West. Bilateral tension between Georgia and Russia and permanent signals of threat, sent from Tbilisi, made allies of Georgia, especially - USA, "keep an eye" on the state. It can be said, that the escalation of tension matched interests of Georgia, and in some moments probably was even stimulated. Only being at the heart of tension or even balancing on the edge of the conflict, Georgia could hope for extraordinary attention of USA. Otherwise the USA, busy with conflicts in Iraq and Afghanistan, problems with Iran, could simply "forget" about Georgia.

Political crisis of the end of 2007 could lead international community to doubt the rationality of the heads of Georgia. Permanent emphasize of the threat of Russia, which was not always grounded, strengthened sceptical moods amongst NATO members. How events of August 2008 showed, Georgia has been very sensitive to the provocations from Russia, and the reaction chosen was probably inadequate.

One of the most important factors, increasing Georgia's attraction for the West, is the fact that Georgia distinguishes from the general context of South Caucasus as having very strong European identity. If Armenia, in a lesser extent - Azerbaijan, shows aspirations to be considered as belonging to Europe, at the same time Georgia demonstrates clear and strong European identity and desire to integrate in European structures. ${ }^{34}$ The identity of Georgia serves as some kind of Guarantee for the West, that the state will not easily shift towards alliance with other great power (for example, Russia) and that "political investment" of the West to Georgia would not be easily eliminated.

In recent years Georgia made sufficient progress in the sphere of military reforms (shift from IPAP toward intensive dialogue witnesses about it). The biggest efforts in reforming military forces were directed to meet the standards of NATO, especially - in the sphere of international crisis management. On the other hand, it weakened Georgia's readiness to perform territorial defence or the ability to take part in a wide-range conventional war. The war with Russia raised some doubts, whether the direction of the reformation of military sector has been chosen rationally and, even more, whether this direction is suitable for such a state like Georgia. Only small professional army was left inside the country, when the main part of military forces served outside the borders

\footnotetext{
${ }^{33}$ REUTERS, U.S. says doubts Russia involved in Georgia strife, 2007 11 13, http://www.reuters.com/article/ worldNews/idUSL1367375720071113.

${ }^{34}$ Tsisikarishvili S., "On the Southern Caucasus' perspectives of becoming Euro-Caucasus" in LithuanianFforeign Policy Review, No. 17, 2006, p. 144-151, 144-145.
} 
of Georgia (in Iraq served 2,000 soldiers of Georgia). What is more, internal military forces in Georgia were based on reservists who passed only minimal military trainings. Matthew Bryza, assistant deputy of State Secretary of USA, stated that after the war with Russia Georgia probably should rethink the structure of the military forces. ${ }^{35}$

NATO Secretary General Jaap de Hoop Scheffer during the visit in September 2008 emphasized, that the way to NATO is still open for Georgia, but further reforms are necessary. Sheffer reminded for Georgia's authorities both parliamentary elections, which were not without frauds and slow the way to democracy. ${ }^{36}$

Russian-Georgian conflict, which broke out in August 2008, has raised many concerns for the West, but also raised a big number of issues, concerning the future of the security of Georgia. The states of NATO countered the dilemma: to surrender the moral pressure of Georgia and to admit the state to NATO as soon as possible, and, as a consequence - to take the responsibility for "hot" conflict in South Ossetia, or not to hurry, providing Georgia security guarantees, but at the same time to show indirectly, that Russia this time was able to block decision on the expansion of NATO.

\subsection{Paradoxes of the Risky Strategy}

After the summit in Bucharest and the promise for future NATO membership, given to Georgia and Ukraine, tensions between Georgia and Russia started to rise. But it is worth to mention that rise of tension between those two neighbours is nothing new (embargo for Georgian wine and mineral water in 2006, scandal of spies in 2007 in Russia's embassy in Georgia). Even more, high tensions in bilateral relations in the past few years became a norm. So this time nobody expected anything extraordinary.

In August 2008, Sakashvili decided to take serious steps to restore territorial integrity of the state and for this reason, introduced military forces to South Ossetia. Now it seems that Russia was waiting for such a decision from the side of Georgia. After this, Russia tried to make view of the "operative reaction", and introduced its own military forces, which had been accumulated for some time already. According to the opinion of military experts, if Russia was truly reacting to the moves of Georgia, counterattacks would have taken place much later, because Russian troops and military equipment could reach South Ossetia only through Roki tunnel.

Military actions between Russia and Georgia started on the $8^{\text {th }}$ of August and lasted till the $22^{\text {nd }}$ of the same month. Nevertheless Russia was stating

\footnotetext{
${ }^{35}$ Eurasia Insight, Kucera J., Georgia: US Congress approves reconstruction aid package for Georgia, 30 09 2008, http://www.eurasianet.org/departments/insight/articles/eav093008b.shtml, 05102008.

${ }^{36}$ Eurasia Insight, Lomsadze, G., NATO to Georgia: membership road still “open”, but reform needed, 2008 09 16, http://www.eurasianet.org/departments/insight/articles/eav091608f.shtml.
} 
that it was only defending its citizens in the region, however the actions showed that it was a war against Georgia. From the very beginning, Russia had two opportunities to respond to the actions of Georgia: to push back military forces of Georgia from the territory of South Ossetia (it could be considered as a protection of citizens), or to spread military actions in all the territory of Georgia (this is how it actually behaved). Russia's actions gave real grounds to accuse Russia of war against sovereign state. ${ }^{37}$ The war was useful for Russia for several reasons:

- Russia was seeking to frighten both the ruling regime of Georgia and society by showing what happens when the interests of Russia are ignored.

- Russia sought to destroy the military and economic infrastructure of Georgia (in the time of military actions, Senaki military base, Poti port, part of important railroad links were fully destroyed).

- Russia sought to demonstrate, that Georgia is an unstable state, in which development of economic or other wide-range projects is too risky. Assumed or real, bombing of an oil pipeline Baku-Tbilisi-Ceyahn had to frighten potential investors and to deter them from further development of Russia-bypassing projects (for example, gas pipeline Nabucco).

Military actions were stopped by the mediation of the president of France, Nicolas Sarkozy, who offered the so-called six-point plan. The President of France stated that the main goal for Europe was to stop military actions as soon as possible, not to search for a guilty side or to punish Russia for the use of force. Nevertheless, after the end of military actions, representatives of the West (for example, Chancellor of Germany, Angela Merkel) emphasized, that recent military actions do not close the door for Georgia to enter NATO. These declarations could be evaluated as: (a) a clear decision to fasten the process of admission of Georgia to NATO; or (b) as signal to Russia that it can not alter the agenda of Alliance or have "veto" right in the questions of expansion of NATO.

Nevertheless, when the tension decreased, in the West the declarations on future NATO membership of Georgia became more cautious and even the question about Georgia's responsibility for the August events was raised.

Promises of a NATO membership, given to Georgia in Bucharest, had to calm down Georgia. But later events, which reached their culmination in August, showed that the promise of membership was just the opposite, it stressed Georgia even more. Georgia interpreted this promise not as the evaluation of the country's efforts, but as a clear signal that without rapid restoration of territorial integrity, Georgia will not enter the alliance. We should remember that representatives of Georgia were going to Bucharest to sign MAP, not to listen to abstract promises on even more abstract perspectives. The famous

\footnotetext{
${ }^{37}$ Emerson M., Post-mortem on Europe's first war of $21^{\text {st }}$ century, Centre for European Policy Studies, Policy brief No. 167, August 2008, p. 1.
} 
formulation, which both for the West and for Russia sounded as very brave and unprecedented declaration, for Georgia was the great loss.

As it has been mentioned already, the security strategy of Georgia is not grounded, because the level of security guarantees is being missed. The more aspirations increase, the more "vacuum" of security guarantees is seen. Radical steps of Georgia can be explained by the existence of such a "vacuum": Georgia has already used all the leverages in relations with NATO (geopolitical position, European identity), so it is impossible to gain more influence in relations with the Alliance from the side of Georgia. So, in such a situation it is vital for Georgia to gain any security guarantees or to revise all the security strategy.

One more factor, which perhaps had influence for the decision of Georgia to use military force for resolving of frozen conflicts, was the presidential elections in USA. The victory of the candidate of Democrats, Barack Obama, was very possible. If Obama would come to White House, Georgia could wait the cut in financial aid from USA. Financial aid is necessary for Georgia to proceed military and other reforms, because the state itself has very few of its own resources. So, these tendencies made Georgia raise the task of getting MAP before the end of 2008 .

The situation became even more complicated after Russia de jure recognized separatist Abkhazia and South Ossetia. On the one hand, Russia got the right to keep normal interstate relations with Abkhazia and South Ossetia, and Georgia does not face the problem of separatism anymore. On the other hand, the recognition of breakaway regions has not gained international support and has not caused a "domino" effect, and the international community is treating Abkhazia and South Ossetia as the regions of Georgia. So, in result, frozen conflicts in Georgia became even more frozen: earlier the issue of legal status of these regions was of primary importance, now the contradiction between actors of international community on evaluation of the status of Abkhazia and South Ossetia worsens the situation. From the perspective of international law, this situation is much more complicated that before the recognition of breakaway regions: Russia cannot take back it's recognition of Abkhazia and South Ossetia, and the international community cannot step back from the principle, that these regions are integral part of Georgia.

But de facto situation can be interpreted much easier. Both the West and Georgia understand that Tbilisi has no possibility to return to Abkhazia and South Ossetia anymore. It can be seen as a new possibility not to waste energy on resolution of hopeless conflicts, but to concentrate the efforts towards the preparation for NATO membership. Looking from the perspective of Tbilisi, the present situation has solved the dilemma of Georgia, although in a very painful way, and left only one opportunity - to seek for NATO security guarantees and to become NATO member, although without Abkhazia and South Ossetia. Nevertheless the situation formed by itself, it does not leave any other opportunity for Georgia. 


\section{Conclusions}

As it has been mentioned before, alliance security strategy is a special one because it provides very clear benchmarks for foreign policy and security policy and leads to the formation of a strong relationship between small state and great power as a "supplier of security". The biggest shortcoming of an alliance security strategy is the absence of alternatives. When a small state finds itself in such a difficult security situation as Georgia today, the only possibility left is the implementation of foreign and security policy, designed according to destinations chosen and the goals raised. Now Georgia can only wait for the decision from the side of NATO. Nevertheless, this decision should be quite rapid, because Georgia can not base its security strategy only on aspirations. If NATO will decide to provide Georgia with security guarantees, it will be possible to say, that Georgia has reached its goal to establish strong alliance relationships with Western powers (first - with the USA) at any expense. In the case of negative answer from NATO or the decision to delay the question of Georgia's membership for indefinite period of time, it would mean the need for Georgia to reshape its security strategy. Unfortunately, at the end of 2008 the last scenario seems more possible, because the summit of foreign ministers of NATO in December showed that there are even more doubts on Georgia's membership now than before the events of August.

The internal situation of Georgia is also a very important factor. It is not worth forgetting that changes in security strategy can be projected by the new authority of Georgia already. If Saakashvili will fail to fulfil the promise to ensure the security of the state through NATO membership, his regime may totally loose support in society.

A result of the events in Georgia deepened dilemmas of NATO and widened the cleavage between the members of Alliance even more that before. On the one hand, Russia's actions in Georgia should intensify the process of NATO expansion, trying not to upset membership seeking countries. On the other hand, NATO should be the guarantee of security and stability in the international arena. Georgia's case showed, that the expansion of Alliance could lead to the new wave of conflicts (for example, problem of Crimea in Ukraine), what would discredit the whole Alliance.

The decision of Russia to go to war with Georgia and to recognize Abkhazia and South Ossetia withdraws the possibility for Russia to manipulate the "card" of frozen conflicts anymore. It was thought that unresolved separatist conflicts are the strongest leverage or Russia to block the expansion of NATO. For now Russia also has no leverages to influence NATO policy anymore and has only to wait for the decision of NATO on the future membership of Georgia and Ukraine. What is more important, Russia showed itself as unreliable actor of international community and increased the level of tension in relations with USA. Looking globally the decision to go to war with Georgia made Russia choose a narrower way, leading to confrontation with the West. This can lead 
to dangerous international isolation and unpredictable aggressiveness. Is Georgia's NATO membership worth such a high price? For Moscow maybe yes. Foreign and security policy in Russia has been evaluated by the narrow geopolitical aspect, so any loss in Georgia or Ukraine can be taken as the signs of fall of great power in Moscow.

Both Georgia and Russia have chosen a risky strategy, which widely restricted their own possibilities to change anything in the nearest future in the question of Abkhazia and South Ossetia. At the same time such choices of Tbilisi and Moscow leave no other possibility for NATO as only to act radically. Having in mind, that all the decisions of NATO has to be taken unanimously, the probability, that consensus will be found on more moderate decision, remain very high. Nevertheless this decision that might be called as a moderate one at the moment in the nearest future can appear as a critical hesitation.

To sum it up, the clear choice of Georgia to become a member of NATO, even scarifying possibilities to restore territorial integrity, is not sufficient to guarantee the security of Georgia. Only strong aspirations of Georgia are not enough to convince all the members of Alliance that Georgia is worth to be the member of NATO. Georgia's tactics to increase geopolitical importance of the state and by such a way to keep permanent attention of the West (especially of the USA) reached it's culmination in August 2008. But at the same time, such tactics created the image of Georgia as an unpredictable and unreliable country. Nevertheless Georgia de facto has lost the opportunities to return back breakaway regions of South Ossetia and Abkhazia and the great risk that NATO would not be willing to take the responsibility for the Georgia's security ever has not been eliminated. 